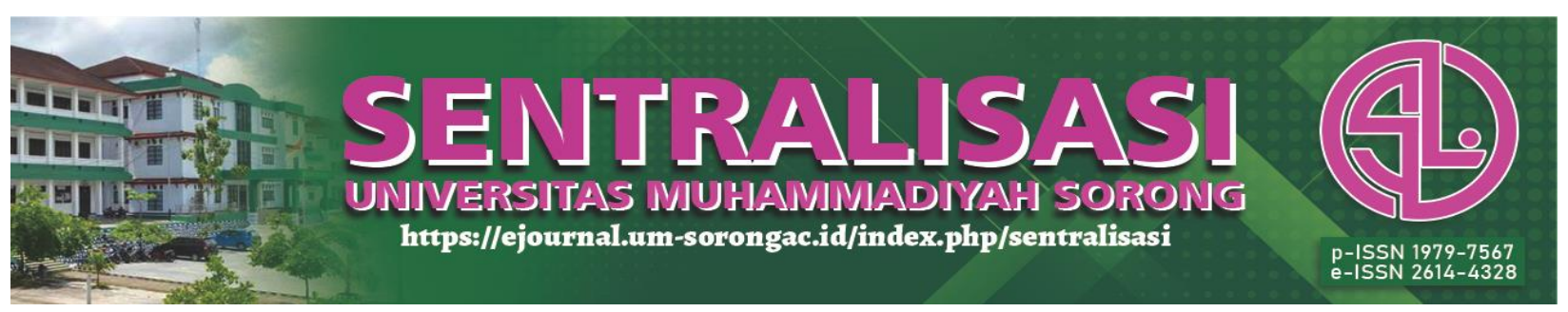

\title{
The Effect of Electronic Word of Mouth on Social Media and The Attraction of Bena Traditional Village Tourism on Tourist Visiting Decisions
}

\author{
Maria Endang Jamu ${ }^{1}$, Santy Permata Sari ${ }^{2}$ \\ 1,2 Program Studi Manajemen, Universitas Flores, Indonesia \\ E-mail :*endangjamu2@gmail.com \\ * corresponding author
}

direvisi: 14/12/2021 dipublikasikan: 08/01/2022

\begin{abstract}
Abstrak. Tujuan dari penelitian ini adalah untuk mengkaji dampak electronic word of mouth di media sosial, serta dampak daya tarik wisata terhadap pengambilan keputusan pengunjung berkunjung di Desa adat Bena. Metode penelitian yang digunakan adalah deskriptif dan kuantitatif. Teknik pengambilan sampel yang digunakan adalah Purposive Sampling, dengan respondennya adalah pengunjung yang pernah berkunjung ke Desa adat Bena. Hasil penelitian menunjukkan bahwa media sosial dan electronic word of mouth (E-WOM) di destinasi pariwisata mempengaruhi keputusan wisatawan untuk mengunjungi Desa adat Bena. Hasil penelitian ini menunjukkan bahwa pengalaman menyenangkan mengunjungi Desa Adat Bena yang dibagikan di platform media sosial seperti Facebook, Instagram, dan WhatsApp berdampak signifikan terhadap jumlah pengunjung objek wisata tersebut oleh pengguna media sosial.
\end{abstract}

Kata Kunci: Electronic Word Of Mouth, Daya Tarik Wisata, Keputusan Berkunjung, Wisatawan

Abstract. The purpose of this research is to examine the impact of electronic word of mouth on social media, as well as the impact of tourist attractions in the traditional hamlet of Bena on visitor decisionmaking. The descriptive and quantitative research methods were applied. The sampling method utilized is purposive sampling, with the informants being visitors who have visited Bena's traditional village. The findings revealed that social media and electronic word of mouth (E-WOM) in tourism destinations influenced tourists' decisions to visit Bena's traditional village. The findings of this study suggest that pleasant experiences of visiting the Bena Traditional Village, which are shared on social media platforms such as Facebook, Instagram, and WhatsApp, have a significant impact on the number of visitors to these attractions by social media users.

Keywords: Electronic Word of Mouth, Tourist Attraction, Decision to Visit, Tourism

\section{Introduction}

In Indonesia, tourism is one sector that has a very important role, one of which is as a foreign exchange earner. Tourism is a new style industry that can provide fast economic growth, provide jobs, is an invisible export, which can bring in foreign exchange directly from the coffers brought by tourists when they spend their money in tourist destination countries. One form of development in the field of tourism is e-tourism. E tourism is utilizing the internet network as an intermediary between tourism service providers and consumers (Lomi \& Bessie, 2016)

According to (Susanto \& Astutik, 2020) Because of this, social media is an excellent technique of promoting a business anyone can access it, so that the promotion network is wide. As a source of tourist information for tourists, the internet has experienced significant developments in recent years.According to a study report published by the Indonesian Internet Service Providers Association (APJII), the number of Internet users in 2019 was 3.3 million, up 


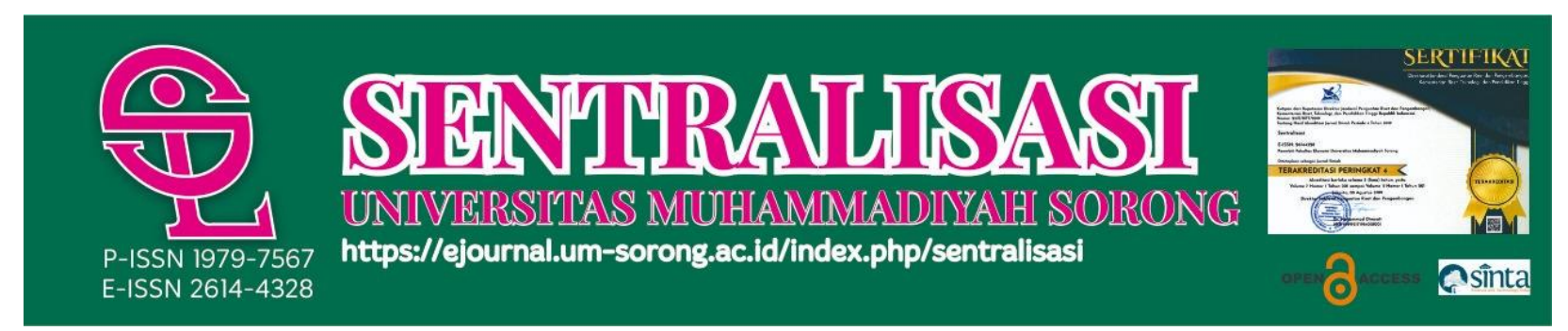

383 thousand from 2.9 million in 2018 (Asosiasi Penyelenggara Jasa Internet Indonesia, 2020). The most popular social media applications in Indonesia when viewed from the frequency of monthly usage, the first place are occupied by Youtube, followed by Whatsapp, Instagram, Facebook, then Twitter in a row. Because of advancements in internet technology, particularly in the usage of social media, word of mouth is no longer limited to face-to-face contact (Harahap et al., 2019).

With the development of technology, more and more consumers want to find information on social networks about a desired product or service so that this will result in electronic word of mouth communication (Hidayanti \& Masyhudi, 2020). Communication built through social media networks will have an impact on tourist visits to certain destinations which will have an impact on those destinations. The information they get from social media will have an impact on visiting interest.Word of mouth (WOM) communication is an efficient marketing method for influencing the decision of potential tourists.

Electronic Word of Mouth (E-WOM) is a social media activity that involves sharing consumer experiences. E-WOM is a favorable or negative statement about a product, company, or media figure that is widely distributed via the internet. (Panwar et al., 2016); (Puspitasari \& Zakky, 2019); (Abubakar et al., 2017); (Handyastuti et al., 2020) Interpersonal influence and WOM are the main sources of information because the intangible nature of tourism products is difficult to evaluate before consumption (Litvin et al., 2008). However, as the internet has grown in popularity, word of mouth has evolved into electronic word of mouth. The rapid development of communication media, especially social media, makes it easier for tourists to share positive or negative impressions and stories that have been felt while traveling (Giam \& Megawati, 2019).

(Mustikasari \& Widaningsih, 2016), stated that the World Tourism Organization revealed that around $95 \%$ of web users use the internet to collect information related to tourism and $93 \%$ visit tourism websites when planning a vacation. According to (Hapsari et al., 2021)that before a tourist travels, they will first seek information about the tourist attraction to be visited one of the sources of information an electronic word of mouth. Positive experiences shared by tourists in the form of photos or stories on social media will have an impact on other tourists who want to visit, they have the same expectations from stories reviewed on social media (Putu Gde Arie, 2018) what is important to note, tourists are those who are selective so it is important for tourist attraction managers be attentive to something existing tourist attractions (Elfitra et al., 2019). According to (Auliya \& Pertiwi, 2020) Tourists use electronic word of mouth as one of the most common forms of communication before visiting a certain attraction. This shows that most tourists get information related to these destinations from the internet, so it is important for stakeholders, in this case the reign of Ngada government, especially the Tourist office, to pay attention to the media used to promote tourism objects in Ngada Regency. 


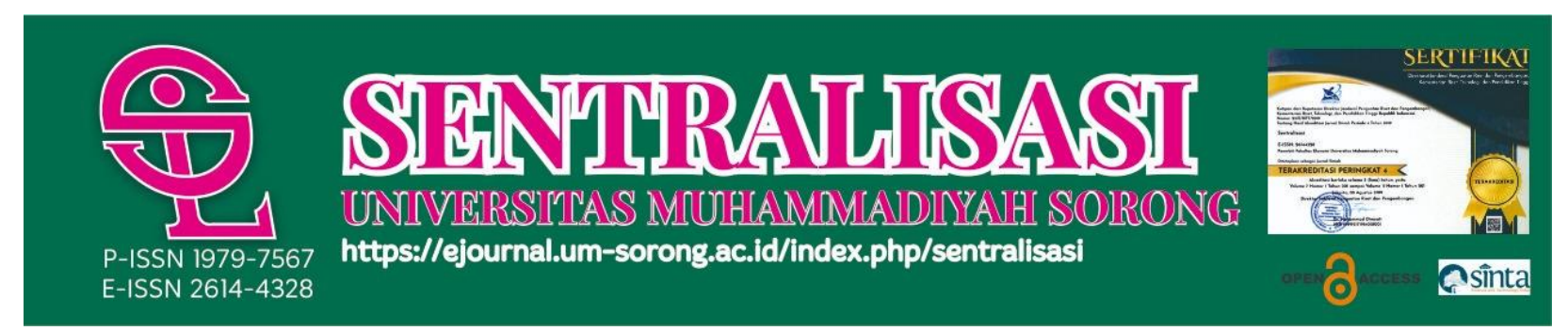

Bena Traditional Village is one of the cultural tourism attractions in East Nusa Tenggara Province's Ngada Regency that has remained popular with visitors in recent years. As shown in the table below

Table 1. Number of Tourist Visits in Bena Traditional Village

\begin{tabular}{ccc}
\hline No & Tahun & Jumlah Kunjungan \\
\hline $\mathbf{1}$ & 2017 & 19.705 \\
$\mathbf{2}$ & 2018 & 16.457 \\
$\mathbf{3}$ & 2019 & 25.613 \\
\hline
\end{tabular}

Source : Ngada Dalam Angka (2020)

The data in Table 1 show that tourists are very interested in visiting the traditional Bena village compared to traditional villages that are also in the same subdistrict. The number of tourist visits that have increased over the last 3 years indicates that the implementation of etourism is likely to run optimally, and will have a good impact on tourism development in East Nusa Tenggara Province, especially in the traditional village of Bena.

\section{Research Method}

The approach used in this study is descriptively quantitative. Data collection techniques with questionnaires. The quantitative data in this study was obtained from respondents' responses to questions asked by researchers in questionnaires. The Likert scale was used in this study, with the following values: SS (Strongly Agree given a score of 5); S (Agree given a score of 4); N (Neutral scored 3); TS (Disagree given a score of 2); STS (Strongly Disagree given a score of 1).

Electronic Word of Mouth is one of the variables in this study, with the following indicators: platform assistance, venting bad thoughts, and concern for other consumers. Tourist attraction indicators are as follows: what to see, what to do, what to buy, what to arrive, what to stay. The decision to visit the indicator is to visit again, seek information. The sampling technique used was purposive sampling. The population in this study was 61,775 (total tourists who visited Bena traditional village for the last 3 years). so to determine the sample using the Slovin formula, namely:

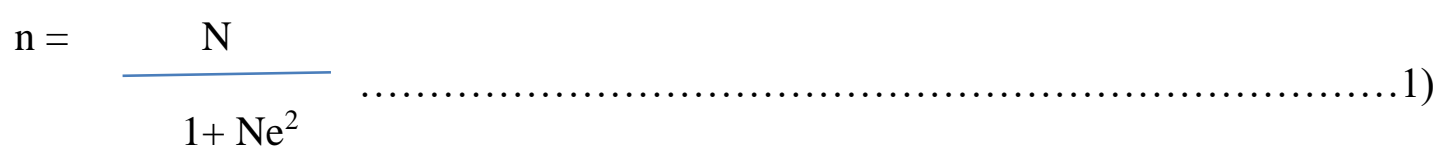

Information:

$$
\begin{array}{ll}
\mathrm{n} & =\text { Sample Size } \\
\mathrm{N} & =\text { Population size } \\
\mathrm{e} & =\text { error tolerence }(0<\mathrm{e}<1) 5 \%
\end{array}
$$

So, the number of respondents is 100 respondents. The equations are as follows: 


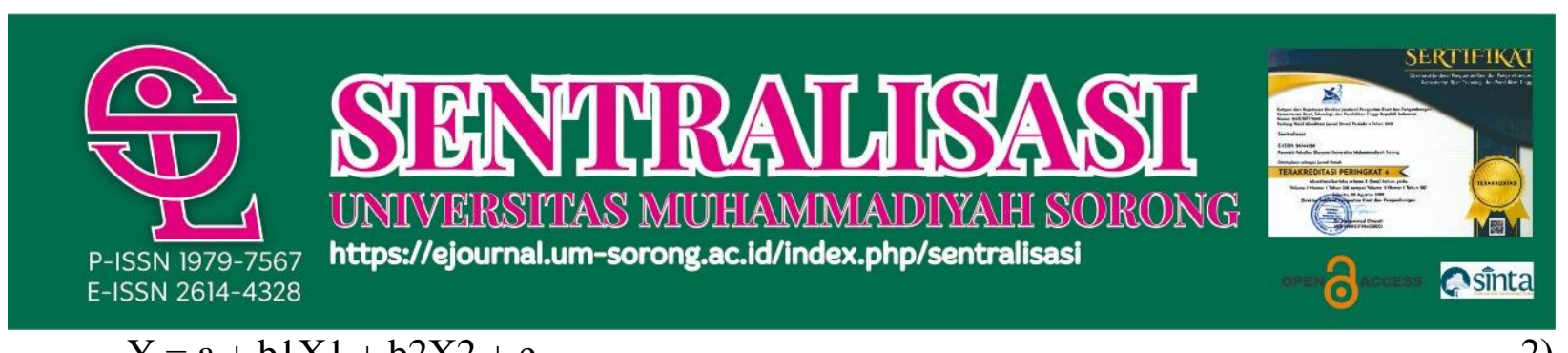

$\mathrm{Y}=\mathrm{a}+\mathrm{b} 1 \mathrm{X} 1+\mathrm{b} 2 \mathrm{X} 2+\mathrm{e}$.

Information :

$$
\begin{array}{ll}
\mathrm{Y} & =\text { Visit Decision } \\
\mathrm{a} & =\text { Constant } \\
\mathrm{b} 1 \mathrm{~b} 2 & =\text { Regression Coefficient } \\
\mathrm{X} 1 & =\text { Electronic word of mouth } \\
\mathrm{X} 2 & =\text { Tourist Attraction }
\end{array}
$$

Using the SPSS 20 program, the data was analyzed using multiple regression analysis.

\section{Result and Discussion}

Bena traditional village is one of the tourists attractions in Ngada Regency which already has a positive image among tourists, both foreign tourists, and domestic tourists. This positive image can be seen from the data (BPS, 2019) which shows that the traditional village of Bena

\begin{tabular}{|c|c|c|c|}
\hline No & \multicolumn{2}{|r|}{ Description of Respondents } & Percentage \\
\hline \multirow{3}{*}{1} & \multicolumn{3}{|c|}{ Gender } \\
\hline & a. & Man & $66 \%$ \\
\hline & b. & Female & $34 \%$ \\
\hline \multirow{5}{*}{2} & & & \\
\hline & a. & 17 to 25 years old & $60 \%$ \\
\hline & b. & 26 to 35 years old & $26 \%$ \\
\hline & c. & 36 to 45 years old & $12 \%$ \\
\hline & $\mathrm{d}$. & 56 years old & $2 \%$ \\
\hline \multicolumn{4}{|c|}{ Profession: } \\
\hline \multirow{4}{*}{3} & a. & Employees of the government & $8 \%$ \\
\hline & b. & Employer & $23 \%$ \\
\hline & c. & Entrepreneur & $9 \%$ \\
\hline & d. & Student & $60 \%$ \\
\hline
\end{tabular}
with the number of visitors is 25,613 is in second place with the highest number of visits. The number of tourists who became respondents in this study was 100, with various characteristics as stated in the table below:

Table 2. Description of Respondents

The usage of social media: 


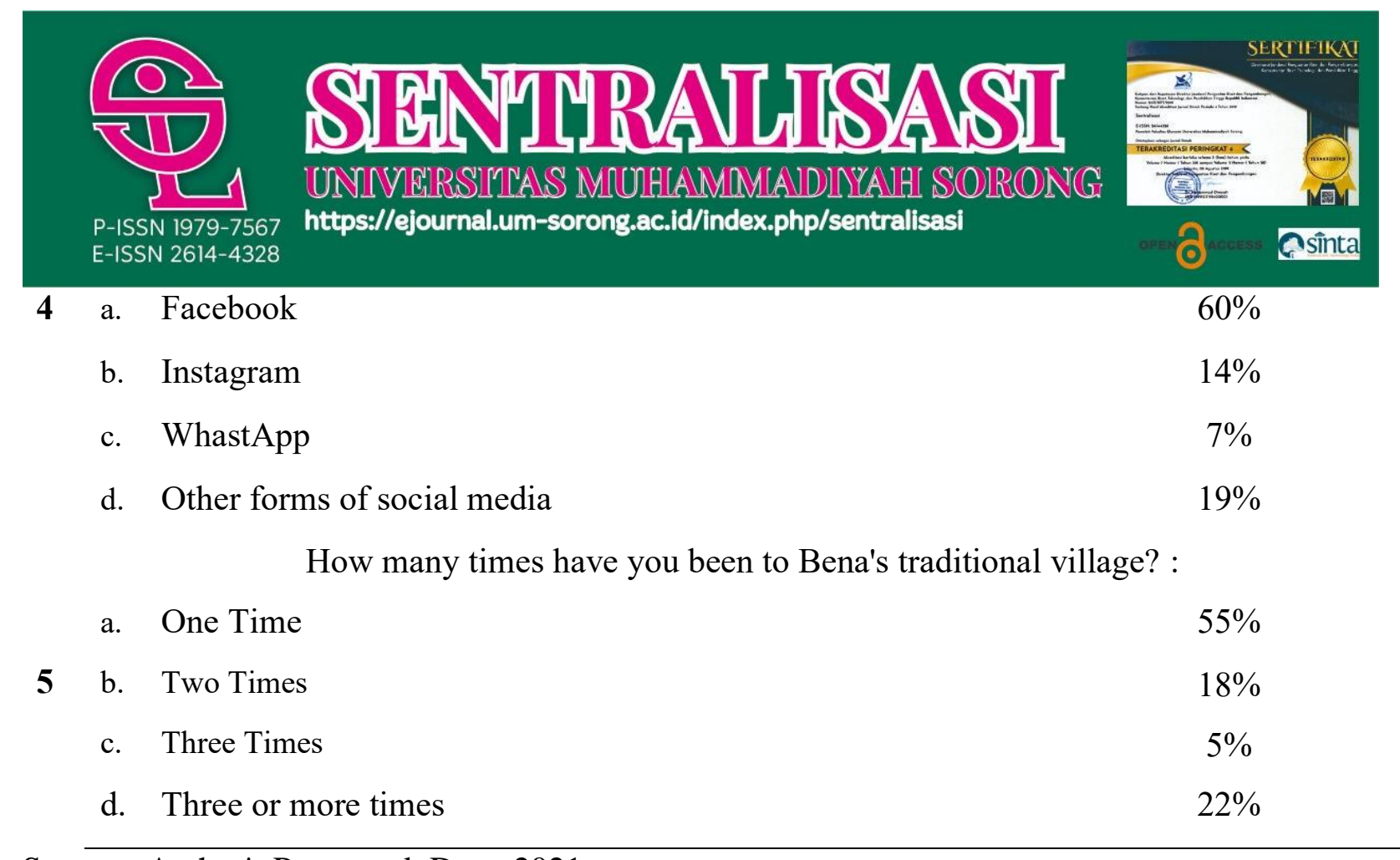

Source : Author's Processed Data, 2021

The general description of the tourists visiting the traditional village of Bena can be found in table 2, where on average those who visit this tourist attraction are teenagers and adults. In addition, the social media used to access information about the traditional village of Bena is Facebook by $60 \%$. Data from (Hootsuite, 2021)shows that the duration of use of each social media, starting from WhatsApp, Facebook, Instagram, Tiktok, and Twitter. Each duration of time required to access information also varies, for WhatsApp, it takes about 30.8 hours each month, 17 hours per monthly on Facebook, and 17 hours per month on Instagram. Tiktok comes in second with 13.8 hours a month of average usage, followed by Twitter with 8.1 hours of instruction.

The existence of an average time spent using social media for a long time, makes tourists have a long time to explore social media, and find information and read information about the experience of traveling in the traditional village of Bena. The positive stories shared by tourists who have visited Bena village are reasons for tourists to visit Bena village.

\section{Classic Assumption Test}

\section{Normality test}

The data from the normality test can be found in the table below, in which the data value of Asymp sig, (2-tailed) is 0.901 , where $0.901>0.050$ so that the data is normally distributed. Here is a table of Normality test, One-Sample Kolmogorov-Smirnov Test:

Table 3. Normality test

\begin{tabular}{llr}
\hline \multicolumn{2}{c}{ One-Sample Kolmogorov-Smirnov Test } \\
\hline $\mathbf{N}$ & & \multicolumn{2}{c}{ Unstandardized Residual } \\
Normal Parameters ${ }^{\text {a,b }}$ & Mean & 100 \\
& Std. Deviation & $0 \mathrm{E}-7$ \\
Most Extreme Differences & Absolute & 2.43339916 \\
& Positive & .057 \\
& & .057
\end{tabular}




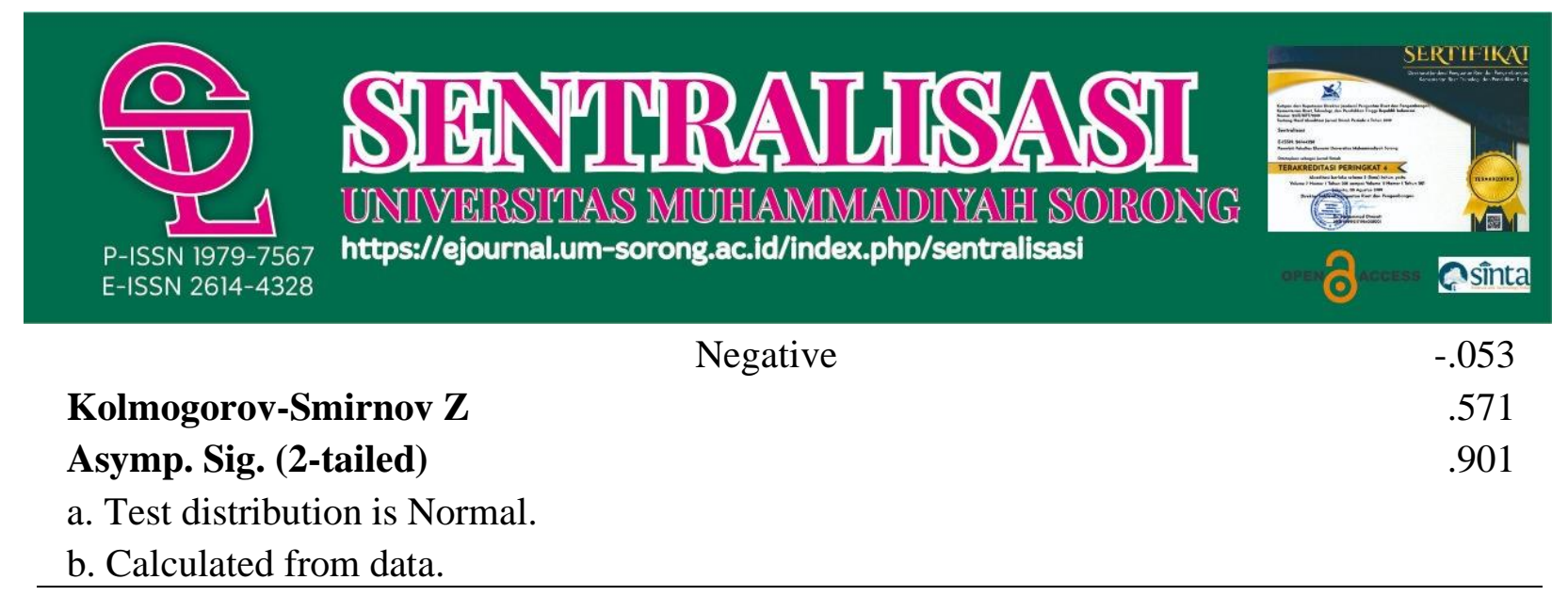

Source : Author's Processed Data, 2021

\section{Linearity Test}

Table 4. e-WOM Linearity Test and Visiting Decisions

\begin{tabular}{|c|c|c|c|c|c|c|c|}
\hline \multicolumn{8}{|c|}{ ANOVA Table } \\
\hline \multirow{7}{*}{$\begin{array}{l}\text { Keputusan } \\
\text { Berkunjung * } \\
\text { eWom }\end{array}$} & & & $\begin{array}{l}\text { Sum of } \\
\text { Squares }\end{array}$ & df & $\begin{array}{l}\text { Mean } \\
\text { Square }\end{array}$ & $\mathrm{F}$ & Sig. \\
\hline & $\begin{array}{l}\text { Betwe } \\
\text { en }\end{array}$ & $\begin{array}{l}\text { (Combin } \\
\text { ed) }\end{array}$ & 795.133 & 15 & 53.009 & 7.630 & .000 \\
\hline & Group & Linearity & 684.300 & 1 & 684.30 & 98.49 & .000 \\
\hline & $\mathrm{s}$ & & & & 0 & 1 & \\
\hline & & $\begin{array}{l}\text { Deviatio } \\
\mathrm{n} \text { from } \\
\text { Linearity }\end{array}$ & 110.833 & 14 & 7.917 & 1.139 & .337 \\
\hline & \multicolumn{2}{|c|}{ Within Groups } & 583.617 & 84 & 6.948 & & \\
\hline & \multicolumn{2}{|l|}{ Total } & $\begin{array}{r}1378.75 \\
0\end{array}$ & 99 & & & \\
\hline
\end{tabular}

Source : Author's Processed Data, 2021

From the table above it can be seen that the value of Sig. Deviation From Linearity is 0.337 , where $0.337>0.050$ which means that the relationship between e-WOM and the decision to visit has a linear relationship.

Table 5. Attractiveness Linearity Test on Visiting Decisions

\begin{tabular}{|c|c|c|c|c|c|c|c|}
\hline \multicolumn{8}{|c|}{ ANOVA Table } \\
\hline \multirow{4}{*}{$\begin{array}{l}\text { Keputusan } \\
\text { Berkunjung * } \\
\text { Daya Tarik }\end{array}$} & \multirow{4}{*}{$\begin{array}{l}\text { Betwee } \\
\mathrm{n} \\
\text { Groups }\end{array}$} & \multirow{3}{*}{$\begin{array}{l}\text { (Combine } \\
\text { d) }\end{array}$} & \multirow{2}{*}{$\begin{array}{l}\text { Sum of } \\
\text { Squares } \\
673.420\end{array}$} & \multirow{2}{*}{$\begin{array}{l}\mathrm{df} \\
1 \\
1\end{array}$} & \multirow{2}{*}{$\begin{array}{l}\text { Mean } \\
\text { Square } \\
51.802\end{array}$} & \multirow{2}{*}{$\begin{array}{c}\mathrm{F} \\
6.316\end{array}$} & \multirow{2}{*}{$\begin{array}{l}\text { Sig. } \\
.000\end{array}$} \\
\hline & & & & & & & \\
\hline & & & & 3 & & & \\
\hline & & Linearity & 616.280 & 1 & 616.280 & 75.142 & .000 \\
\hline & & Deviation & 57.140 & 1 & 4.762 & .581 & .852 \\
\hline & & from & & 2 & & & \\
\hline & & Linearity & & & & & \\
\hline & \multirow{2}{*}{\multicolumn{2}{|c|}{ Within Groups }} & 705.330 & 8 & 8.202 & & \\
\hline & & & & 6 & & & \\
\hline & \multirow{2}{*}{\multicolumn{2}{|c|}{ Total }} & 1378.75 & 9 & & & \\
\hline & & & 0 & 9 & & & \\
\hline
\end{tabular}

Source : Author's Processed Data, 2021 


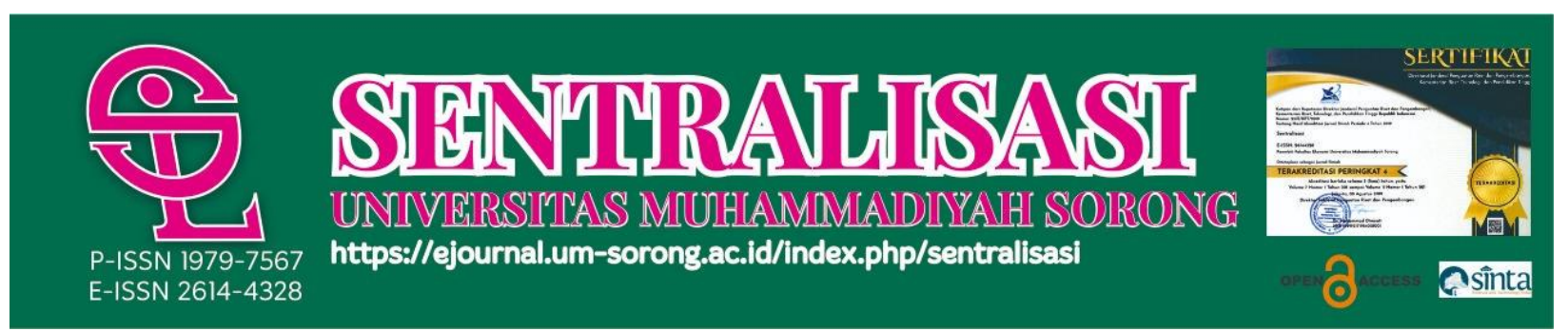

From the table above, it can be seen that the value of Sig. Deviation From Linearity is 0.852 , where $0.852>0.050$ which means that the relationship between attractiveness and the decision to visit has a linear relationship.

\section{Multicollinearity Test}

Table 6. Multicollinearity Test

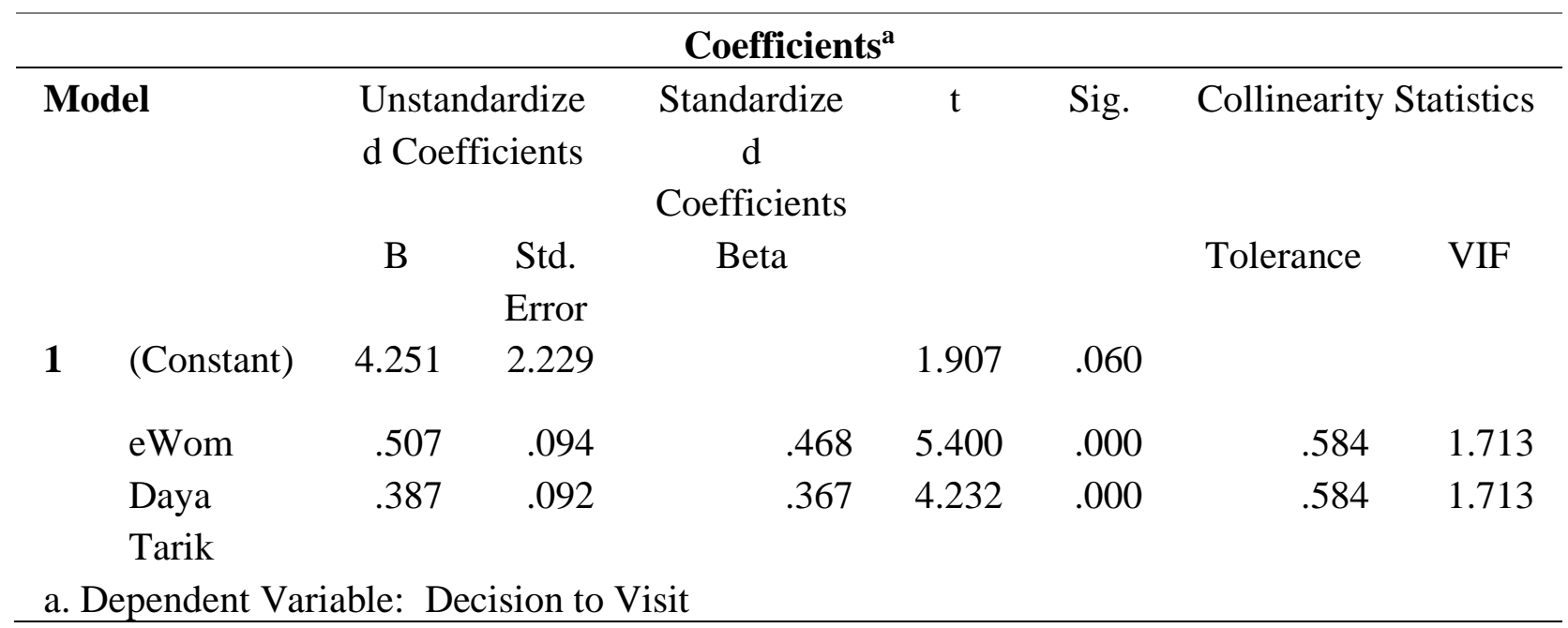

Source : Author's Processed Data, 2021

The Colinearity Statistical Tolerance value is 0.584 , and the VIF value is 1.713 , as shown in the table above, where the Tolerance value is $0.584>0.100$ and the VIF value is 1.71310 .00 , implying that there are no indications of multicollinearity.

\section{Multiple Regression Linear Analysis}

T Test

Table 7. T Test Results

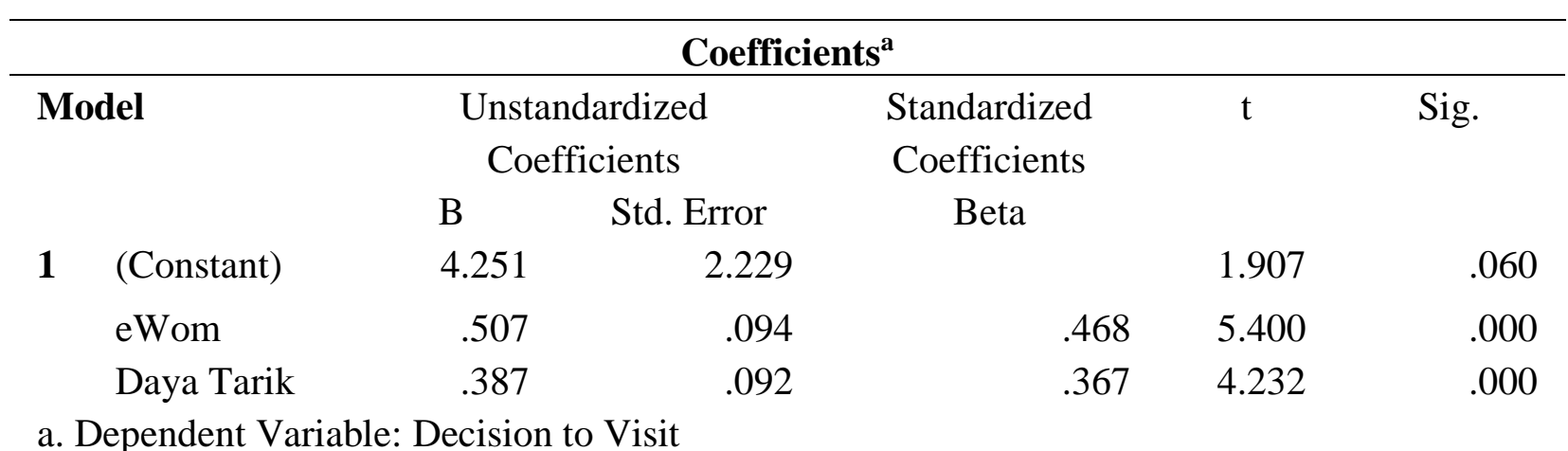

a. Dependent Variable: Decision to Visit

Source : Author's Processed Data, 2021

The regression equation is as follows:

$$
\mathrm{Y}=\mathrm{a}+0.507+0.387+\mathrm{e}
$$

It may be argued, based on the partial test findings above, that the two independent variables, namely e-WOM and attractiveness, have a significant influence $(\operatorname{sig}<0.05)$ on the 


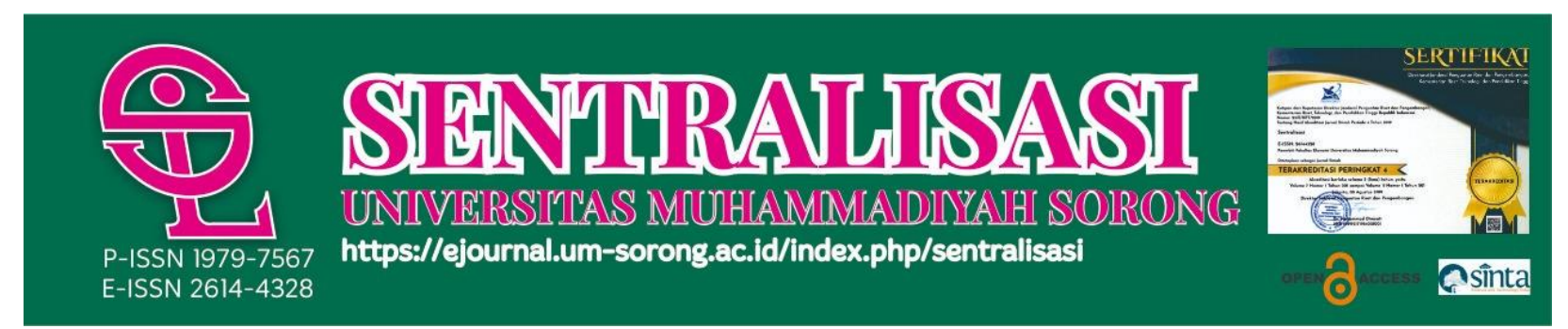

decision to visit. The decision to visit the tourist town of Kampung Bena is influenced by electronic word of mouth in a good and important way. With a significance level of 5\%, hypothesis testing was conducted between the Electronic Word of Mouth variable on the decision to visit, resulting in a $t$ value of 1.98472 , where $t$ arithmetic was $5.400>t$ table was 1.98472 . As a result, it can be argued that Electronic Word of Mouth has a beneficial impact on the decision to visit.

The internet makes communication have various types of interactions, interactions that occur on social media allow the occurrence of the Electronic Word Of Mouth phenomenon (Anggi dkk,2019).Electronic Word Of Mouth (e-WOM) is an online-based marketing communication via social media that includes messages containing good or negative sentiments made by potential or previous customers (Sari \& Pangestuti, 2018); (Alkailani, 2016). E-WOM media is seen as very effective as a form of promotion that is more trustworthy by potential consumers than formal forms of promotion. This is because there are many ways to exchange information to share their experiences among consumers of a product or service that they have experienced themselves (Rofiah, 2020).

The decision to visit the tourist Kampung Bena village is influenced by its attractiveness. This can be seen in the table of the t-test results. Hypothesis testing was carried out between the attractiveness variable and the decision to visit the village of Kampung Bena tourism at a significance level of $5 \%$, so the $\mathrm{t}$ value was 1.98472 where $\mathrm{t}$ count was $4.232>\mathrm{t}$ table was 1.98472. The results of this study are the same as the results of research conducted by (Yuliyani \& Suharto, 2020); (N. D. Susanti et al., 2019)which explains that e-WOM and attractiveness have an influence on visiting decisions.

Prospective visitors who act as recipients of information will more easily trust sources of information that have high credibility, good quality information, have an accurate quantity according to field conditions (Sari \& Pangestuti, 2018)

\section{F Test}

Table 8. F Test Results

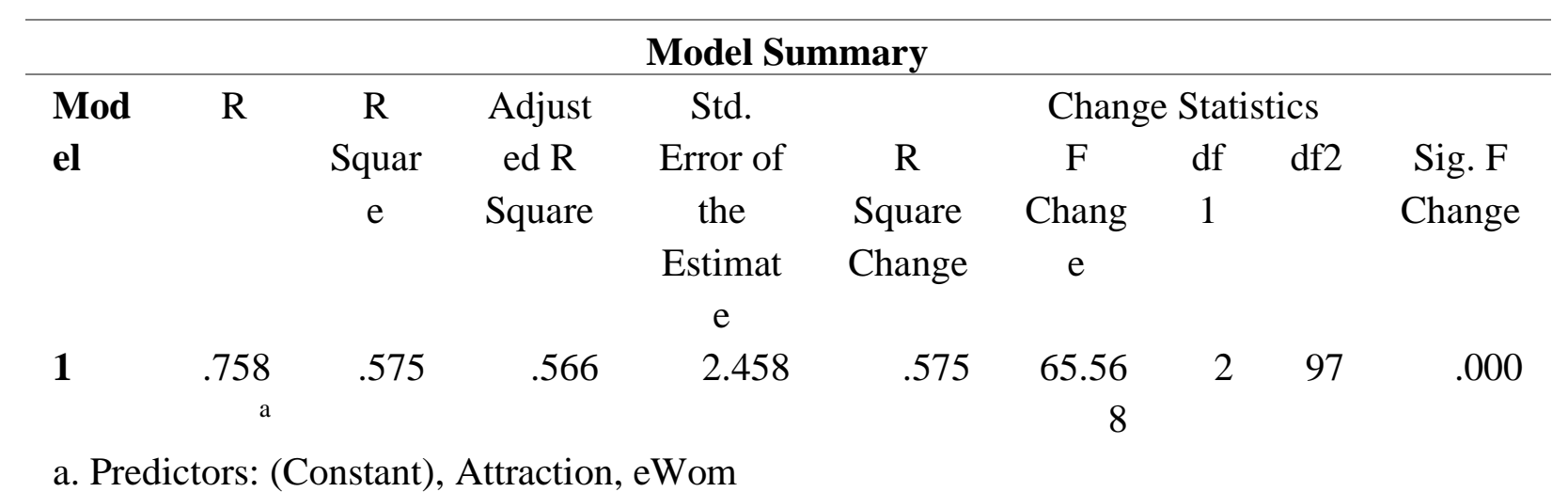

Source : Author's Processed Data, 2021 


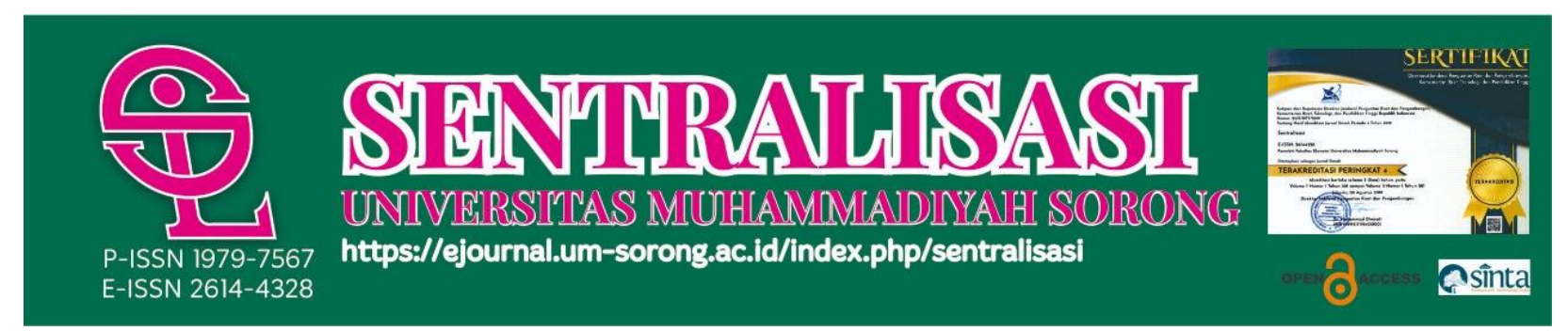

The degree of the influence of e-WOM and tourist attraction on the decision to visit in the study, as evaluated by a coefficient of determination, is shown in the table above or (R2) of 0.575 or $57.5 \%$, this condition indicates that the variables of e-WOM and attractiveness provide influence on the decision to visit Bena Village, while $42.5 \%$ is influenced by other variables that have not been studied.

\section{Coefficient of Determination}

Table 9. Coefficient of Determination

\begin{tabular}{|c|c|c|c|c|c|c|}
\hline \multicolumn{7}{|c|}{ ANOVA $^{\mathrm{a}}$} \\
\hline \multicolumn{2}{|c|}{ Model } & Sum of & $\mathrm{df}$ & Mean Square & $\mathrm{F}$ & Sig. \\
\hline \multirow[t]{3}{*}{1} & Regression & 792.528 & 2 & 396.264 & 65.568 & $.000^{\mathrm{b}}$ \\
\hline & Residual & 586.222 & 97 & 6.044 & & \\
\hline & Total & 1378.750 & 99 & & & \\
\hline
\end{tabular}

a. Dependent Variable: Decision to Visit

b. Predictors: (Constant), Attraction, eWom

Source : Author's Processed Data, 2021

The estimated $\mathrm{f}$ value is 65,568 with a significance of 0.0000 .050 , implying that the hypothesis indicates that e-WOM and tourist attraction have a simultaneous effect on the desire to return. This study shows that e-WOM and attractiveness affect the decision to visit. This backs up the findings of prior study (N. Susanti et al., 2019) which stated that tourist attraction and eWOM affected visiting decisions.

The decision to visit which is influenced by tourist attractions promoted through social media has had a positive impact. SFor many businesses, social media has become an essential part of their marketing strategy and is one of the most effective ways to reach out to customers and clients (E. S. Setiyorini et al., 2018) (Mulyati \& Masruri, 2019) ( A. Setiyorini et al., 2018 )

According to Nasrullah (Puspitarini \& Nuraeni, 2019) Social media is an online platform that allows individuals to express themselves, cooperate, share, communicate, and develop virtual ties with other people. The presence of built-in communication has motivated tourists to visit Bena's traditional village.

\section{Conclusion}

Several conclusions were obtained based on the research and data analysis, including: First, electronic word of mouth on social media has a beneficial impact on decisions regarding tourists visiting. Favorable travel experiences published on personal social media have had a positive impact on other travelers interested in visiting the Bena Traditional Village. Second, the attractiveness of tourists has a good impact on the decision to visit them. The beautiful scenery, 


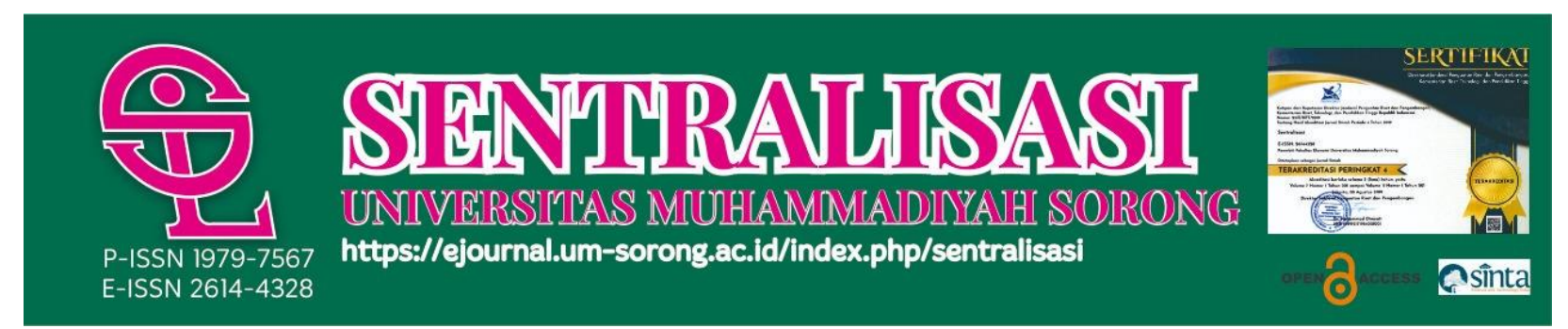

the value of cultural elements that are still well maintained and preserved have an impact on tourists to visit Bena Traditional Village. Third, social media has had a positive influence on tourists who want to visit Bena Traditional Village.On their various social media profiles, interesting photographs and videos have piqued the interest of other travelers who want to visit.

Electronic word of mouth is one of the most effective marketing tactics communication techniques using social media to reach all people, starting with a tourist's age, occupation, and residence. Bena traditional village is not only visited by local tourists but from various regions, therefore, it is hoped that the Ngada Regency government, especially the Tourism Office, always carries out promotions on social media and existing websites, so that tourists can access information quickly and reliably. Furthermore, based on the findings of this study, the Ngada Regency Tourism Office should pay attention to Electronic Word of Mouth, which is distributed through social media, in order to promote visitor interest in visiting Bena village. This study still has limitations on the sample, therefore for further research, it is hoped that it can add foreign tourists as respondents and add variables.

\section{Acknowledgement}

The researcher thanks the Ministry of Research, Technology and Higher Education for funding this research activity, as well as the director of the Institute for Research and Community Service at the University of Flores and the head of the National Research Center. The Office for Unity, Politics and Community Protection of the Ngada Regency, the traditional Bena village community and investigators helped with the data collection.

\section{References}

Abubakar, A. M., Ilkan, M., Al-Tal, R. M., \& Eluwole, K. K. (2017). eWOM, revisit intention, destination trust and gender. Journal of Hospitality and Tourism Management, 31, 220-227.

Alkailani, M. (2016). Electronic Word Of Mouth (Ewom) And Its Effect On Consumers'Decisions To Buy Products And Services In Traditional Stores In Jordan. Journal of Competitiveness Studies, 24(4), 237.

Asosiasi Penyelenggara Jasa Internet Indonesia. (2020). Laporan Survei Internet APJII 2019 2020. Asosiasi Penyelenggara Jasa Internet Indonesia, 2020, 1-146. https://apjii.or.id/survei

Auliya, Z. F., \& Pertiwi, I. F. P. (2020). The Influence of Electronic Word of Mouth (E-WOM) and Travel Motivation toward the Interest in Visiting Lombok, Gender as a Mediator. INFERENSI: Jurnal Penelitian Sosial Keagamaan, 13(2), 201-218. https://doi.org/10.18326/infsl3.v13i2.201-218 


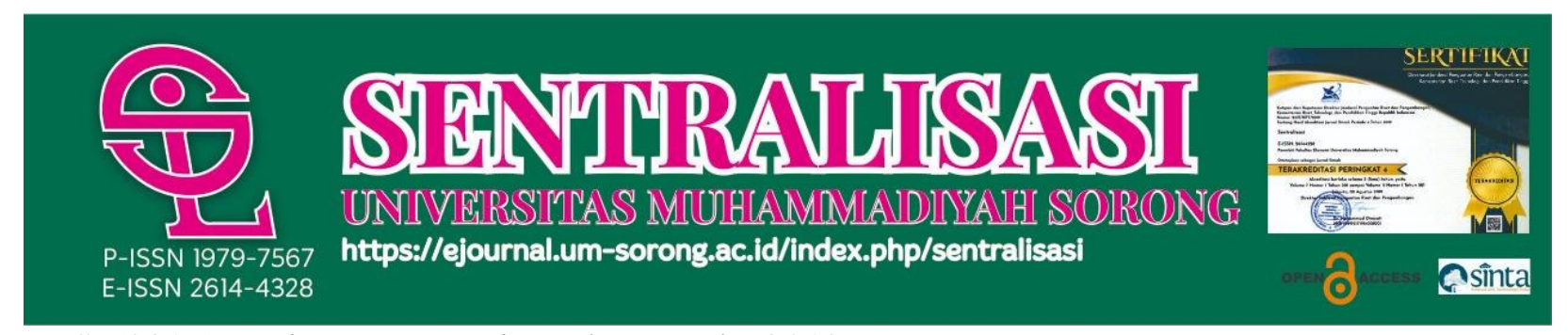

BPS. (2019). Kabupaten Ngada Dalam Angka 2019.

Elfitra, S. D., Saragih, M. G., \& Khoerunisa, A. W. (2019). Analysis Of The Effect Of Electronic Word Of Mouth, Nalysis Of The Effect Of Electronic Word Of Mouth, Tourism Products And Destination Images On Decision Ourism Products And Destination Images On Decision Visiting Tourists To Toba Lake Tourism Visiting t. The 1st MultiDiscipinary International Conference University Of Asahan2019 He 1st MultiDiscipinary International Conference University Of Asahan2019 Thema: The Role of Science in Development in the Era of Industrial Revolusion Thema: The Role of Science, 471-482.

Giam, H. S., \& Megawati, Y. (2019). Impact of Electronic Word of Mouth Social Media on the Decision to Choose Nusa Penida as a Tourist Destination with Mediated e-Trust. Jurnal Hospitality Dan Pariwisata, 5(1).

Handyastuti, I., Harmoni, A. H., Nuraeni, E., \& Lating, F. I. (2020). The Influence of Electronic Word of Mouth (e-WOM) on Travel Decision in Bandung City. Digital Press Social Sciences and Humanities, 4(Ihtf), 00010. https://doi.org/10.29037/digitalpress.44357

Hapsari, N. R., Lubis, N., \& Widiartanto. (2021). Pengaruh Atribut Produk Wisata Dan Electronic Word Of Mouth ( EWOM ) Terhadap Keputusan Berkunjung Pada Obyek Wisata Umbul Manten Klaten. E-Proceeding of Management:, 8(1), 152-163.

Harahap, A. A. T., Haryono, S., \& Hadi, L. (2019). Pengaruh electronic word of mouth terhadap destination image dan dampaknya pada keputusan pembelian. Jurnal Administrasi Bisnis (JABis), 17(2), 50-59.

Hidayanti, O. A. A., \& Masyhudi, L. (2020). Pengaruh Electronic Word Of Mouth, Daya Tarik Dan Lokasi Terhadap Minat Berkunjung Wisatawan Di Desa Tete Batu Kabupaten Lombok Timur. Jurnal Inovasi Penelitian, 1(2), 129-144.

Hootsuite. (2021). Digital 2021. Global Digital Insights, 103.

Litvin, S. W., Goldsmith, R. E., \& Pan, B. (2008). Electronic word-of-mouth in hospitality and tourism management. Tourism Management, 29(3), 458-468.

Lomi, A. G., \& Bessie, J. L. . (2016). Pengaruh Electronic Word of Mouth Pada Media Sosial Facebook Terhadap Minat Beli Konsumen (Studi pada Tebing Bar dan Cafe). Journal Of Management, 2(1), 29-58. http://ejurnal.undana.ac.id/JEM/article/download/1200/950

Mustikasari, A., \& Widaningsih, S. (2016). Pengaruh e-wom terhadap keputusan berkunjung ke tempat wisata di kota bandung. Jurnal Manajemen Indonesia, 16(2), 95-103.

Panwar, A., Jain, R., \& Rathore, A. P. S. (2016). Obstacles in lean implementation in developing countries-some cases from the process sector of India. International Journal of Lean Enterprise Research, 2(1), 26-45. 


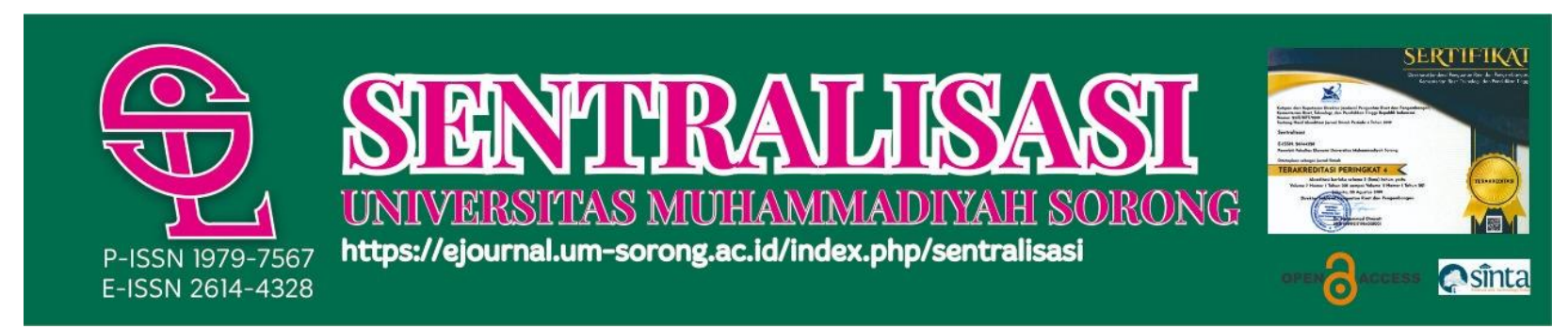

Puspitarini, D. S., \& Nuraeni, R. (2019). Pemanfaatan Media Sosial Sebagai Media Promosi. Jurnal Common, 3(1), 71-80.

Puspitasari, U., \& Zakky, F. A. (2019). Pengaruh Kepuasan Konsumen, Kepercayaan, Dan Kualitas Produk Terhadap Wom Communication: Studi Pada Produk Nature Republic Aloe Vera 92\% Soothing Gel. Iain Surakarta.

Putu Gde Arie, Y. (2018). The Effect Of E-wom On Social Media Instagram Toward The Decision To Visit Labuan Bajo. JBHOST, 151(2), 10-17.

Rofiah, C. (2020). Pengaruh Electronic Word Of Mouth Terhadap Keputusan Berkunjung Dimediasi Oleh Citra Destinasi. Manajemen Dan Bisnis Dewantara, 3(1), 32-39. ejournal.stiedewantara.ac.id/index.php/JMD/issue/view/50\%0AHalaman

Sari, F., \& Pangestuti, E. (2018). Pengaruh Electronic Word of Mouth (E-Wom) Terhadap Minat Berkunjung dan Keputusan Berkunjung (Studi pada Wisata Coban Rais BKPH Pujon). Jurnal Administrasi Bisnis (JAB), 54(1), 189-196. http://administrasibisnis.studentjournal.ub.ac.id/index.php/jab/article/view/2231

Setiyorini, E. S., Noorachmat, B. P., \& Syamsun, M. (2018). STRATEGI pemasaran produk olahan hasil perikanan pada UMKM Cindy Group. MANAJEMEN IKM: Jurnal Manajemen Pengembangan Industri Kecil Menengah, 13(1), 19-28.

Susanti, N., Aryati, I., \& Damayanti, R. (2019). Historis, Daya Tarik Wisata Dan Electronic Word Of Mouth (e-Wom) Terhadap Keputusan Berkunjung Di De Tjolomadoe. Jurnal Riset Bisnis Dan Manajemen, 12(2), 59-63.

Susanti, N. D., Aryati, I., \& Damayanti, R. (2019). Historis, Daya Tarik Wisata Dan Electronic Word of Mouth (E-Wom) Terhadap Keputusan Berkunjung Di De Tjolomadoe. Jurnal Riset Bisnis Dan Manajemen, 12(2), 59-63. https://doi.org/10.23969/jrbm.v12i2.1424

Susanto, B., \& Astutik, P. (2020). Pengaruh Promosi Media Sosial Dan Daya Tarik Wisata Terhadap Minat Berkunjung Kembali Di Obyek Wisata Edukasi Manyung. Jurnal Riset Bisnis Dan Ekonomi, xx(x), 46-56.

Yuliyani, Y., \& Suharto, S. (2020). Upaya Warga Masyarakat Dusun Bembem Trimulyo Jetis Bantul dalam Mewujudkan Sungai Opak Sebagai Wisata Sungai (River Tourism). Jurnal Hotelier, 6(1), 12-24. 